\title{
Bark Stripping from Forest Tree Species in Madjadjane, Southern Mozambique: Medicinal Uses and Implications for Conservation
}

\author{
Annae M. Senkoro ${ }^{*}$, Filomena M. A. Barbosa ${ }^{1}$, Sharmila F. Moiane1, Gabriel Albano², \\ Ana I. Ribeiro de Barros 3,4 \\ ${ }^{1}$ Faculty of Sciences, Eduardo Mondlane University (UEM), Maputo, Mozambique \\ ${ }^{2}$ Faculty of Agronomy, UEM, Maputo, Mozambique \\ ${ }^{3}$ Tropical Research Institute, Oeiras, Portugal \\ ${ }^{4}$ Biotechnology Center, UEM, Maputo, Mozambique \\ Email: ${ }^{*}$ asenkoro@uem.mz
}

Received 4 January 2014; revised 6 February 2014; accepted 4 March 2014

Copyright (C) 2014 by authors and Scientific Research Publishing Inc.

This work is licensed under the Creative Commons Attribution International License (CC BY). http://creativecommons.org/licenses/by/4.0/

(c) (i) Open Access

\section{Abstract}

Tree bark is one of the most important non-timber forest products. In less developed countries, it is used for multiple purposes, particularly in traditional medicine. This paper addresses the question of bark exploitation, uses, and impacts in Madjadjane village, southern Mozambique. For that, we have conducted an ethnobotanical survey and analysed the level of damage of the ten most exploited tree species. Bark was mainly used for medical purposes, spanning 13 different applications. Most of the species had more than one medical application constituting potential sources of valuable biocompounds. In general the level of damage caused by debarking was not critical, but should be seen with caution. An upgrade and update of the results will be of utmost importance to estimate with more accuracy the current conservation status as well as to predict future impacts and define better conservation strategies. We suggest the expansion of ethnobotanical surveys as well as their integration in broad programs aimed at the preservation and valorization of local heritage. This will encourage equitable access and benefit sharing of biodiversity as well as the promotion of bio-based economy.

\section{Keywords}

Bark, Ethnobotany, Traditional Knowledge, Conservation, Mozambique

\footnotetext{
"Corresponding author.
}

How to cite this paper: Senkoro, A.M., et al. (2014) Bark Stripping from Forest Tree Species in Madjadjane, Southern Mozambique: Medicinal Uses and Implications for Conservation. Natural Resources, 5, 192-199. 


\section{Introduction}

Forests and woodlands are key providers of social, economic and ecological services that go far beyond timber exploitation. Tree bark is one of the most important non-timber forest products. In many regions of the developing world, bark has been used for a wide range of purposes such as beehives, fiber, tannin, and in particular traditional medicine [1].

The term bark refers to all tissues outside the vascular cambium, comprising dead and live tissue. The dead tissue (rhytidome) corresponds to the outer layer of bark, functioning as a physical barrier that protects the tree against desiccation, fire, insects, herbivores and diseases. The live tissue (phloem) constitutes the inner bark, playing a key role in nutrient transport [2]. Thus, if no appropriate measures are taken, debarking may impose irreversible injuries, compromising tree survival, growth and reproduction.

In Mozambique roughly $90 \%$ of the country's population depends on plant resources to fulfill its housing, food, energy and health needs. In fact, some $15 \%$ of the local flora (5500 species) has a multipurpose function [3]. However, good conservation outcomes of these resources will depend highly upon users and their livelihood strategies. Like elsewhere in the region, livelihood strategy allied to trends of population growth is among the major threats to the ecosystem health. These may compromise resource availability particularly in countries with low human development indices where incremental expansion of cultivated lands restrains the potential of ecosystem services [4]. In Mozambique, for example, natural ecosystems are over-exploited and conservation projects are a major challenge [5]. On the other hand, the traditional use of plant genetic resources is progressively reduced, due to the exodus of young people from rural to urban places [6]. Thus, the documentation of local plant uses is of utmost importance, not only to preserve traditional knowledge, but also to facilitate conservation efforts.

In this paper we present the results of a survey on the use of bark of ten tree species as well as the estimation of the level of damage due to debarking, in Madjadjane village, district of Matutine, Maputo Province. The work was integrated in the Natural Resources Management program under the International Union for Conservation of the Nature (IUCN).

\section{Methods}

\subsection{Study Area}

This study was carried out in Madjadjane, Matutuine district, Maputo province $\left(26^{\circ} 25^{\prime}\right.$ and $26^{\circ} 32^{\prime} \mathrm{S}$; $32^{\circ} 17^{\prime}$ and $32^{\circ} 22^{\prime} \mathrm{E}$ ) (Figure 1). The climate is subtropical with two main seasons, wet from October to April and dry from May to September. The mean annual rainfall is $1000 \mathrm{~mm}$. The mean annual temperature is over $24^{\circ}$ and relative humidity varies from $55 \%$ to $75 \%$.

\subsection{Ethnobotanical Data Collection (Bark Use)}

The work was initiated following a meeting between researchers, community leaders and the Commission of Natural Resources Management, in order to: 1) explain the aim and importance of the work; 2) receive cooperation and permission to use the cultural heritage; 3) collect information for structuring the interviews; 4) give orientations for the selection of informants by age and gender; and 5) plan the field activities. Sixty six informants (out of 600 inhabitants) were selected as the best traditional knowledge holders. The selection criteria were based on the size of the study site, the vegetation homogeneity and on the indications provided by the community (i.e. traditional medicine practitioners, collectors and traders, people dealing with arts and crafts). Using standard methods [7], the data were collected through intensive structured interviews and complemented by semi-structured interviews in the local language (i.e. Ronga). Questions included common and local names of the plants as well as applications.

\subsection{Plot Design and Species Identification}

Twelve stratified transects were established. The distance between transects was $100 \mathrm{~m}$. Data were scored in five plots $(20 \mathrm{~m} \times 20 \mathrm{~m})$ per transect, separated from each other by a distance of $50 \mathrm{~m}$ [8]. Species identification was carried out in the field and by comparing voucher specimens with specimens deposited at the Herbarium of the Faculty of Sciences, Eduardo Mondlane University (LMU, Maputo, Mozambique). The scientific names were confirmed through specialized bibliography [9] as well as the African Plant Database [10]. 


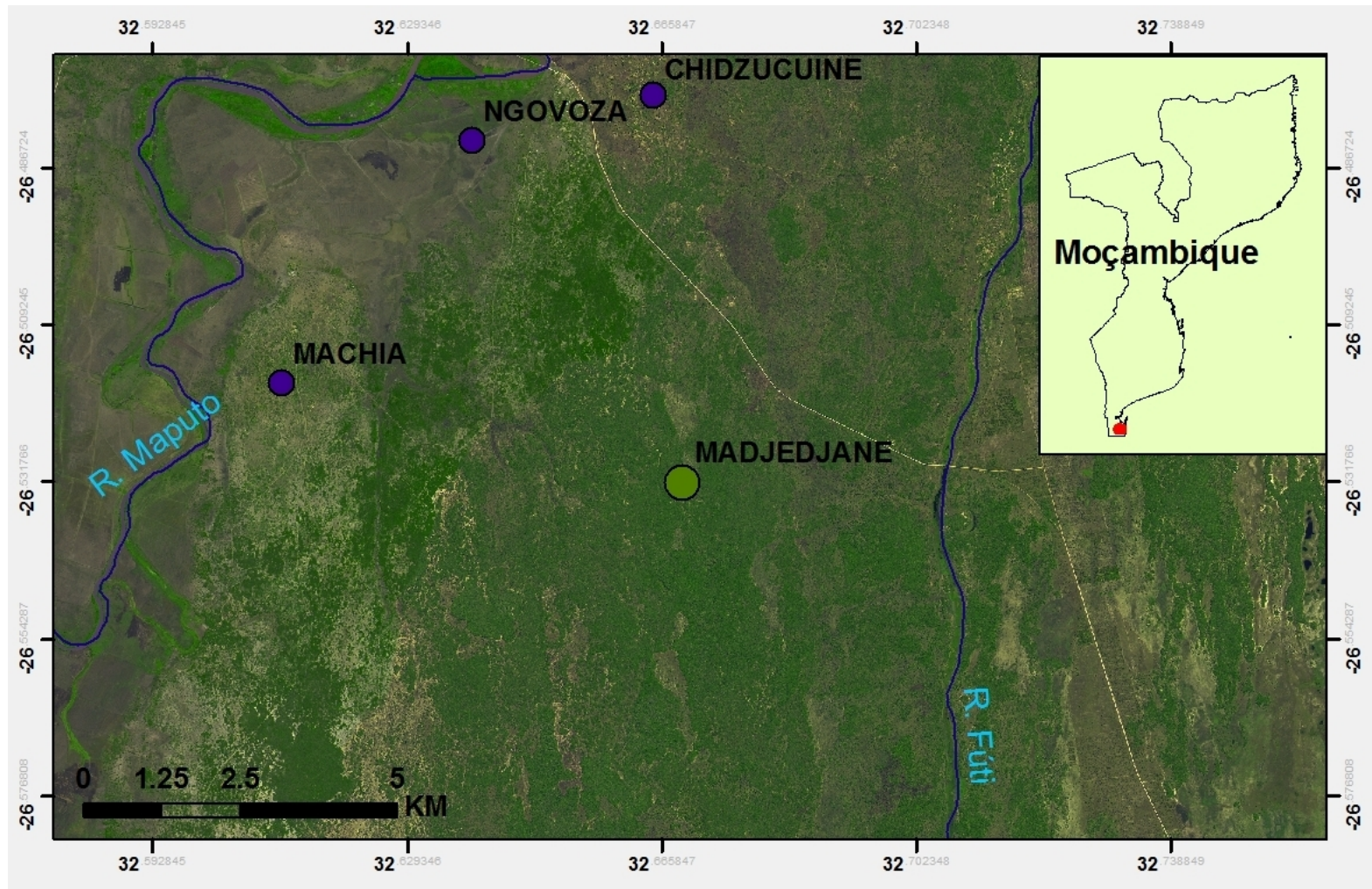

Figure 1. Map of the study site. R. Futi = Futi River; R. Maputo = Maputo River (Hugo Mabilana, Department of Biological Sciences, Faculty of Sciences, Eduardo Mondlane University).

\subsection{Specific Density and Level of Damage}

Species density was calculated according to [8]: $\mathrm{D}=\mathrm{N} / \mathrm{A}$, where $\mathrm{D}=$ specific density; $\mathrm{N}=$ number of individuals; $\mathrm{A}=$ plot area. The level of damage was calculated for the ten most exploited species, selected according to the interviews, species density and the literature [11] [12]. The area of the removed bark was calculated assuming it was rectangular: $A_{r}=C \times L$, where $A_{r}=$ stripped area; $C$ = length of the wound (removed bark); $L=$ width of the wound. The volume of the stripped bark was also determined according to the formula: $V_{b}=A_{r} \times T$, where $V_{b}=$ volume of the stripped bark; $A_{r}=$ stripped area; $T=$ thickness of the removed bark. The potentially exploitable bark volume was calculated according to the following formula: $V_{p e}=V_{1}-V_{2}$, where $V_{p e}=$ potentially exploitable bark volume; $\mathrm{V}_{1}=$ total stem volume $\left[\mathrm{V}_{1}=\pi \times \mathrm{r}_{1}^{2} \times \mathrm{h}_{\max }\right.$ where, $\mathrm{r}_{1}=$ stem circle radius $=$ diameter-at-breast height (dbh)/2; $h_{\max }=$ maximum wound height)]; $V_{2}=$ volume of the inner stem $\left[V_{2}=\pi \times r_{2}^{2}\right.$ $\times \mathrm{h}_{\max }$ where, $\mathrm{r}_{2}=$ stem circle radius - thickness of removed bark]. The percentage of damage was finally calculated: \% Damage $=\mathrm{V}_{\mathrm{b}} \times 100 / \mathrm{V}_{\mathrm{pe}}$, and grouped into three categories: low $(<30 \%)$; medium $(30 \%-60 \%)$ and high (>60\%). Data were compiled and analysed with the excel package from Microsoft Office 2007.

\section{Results and Discussion}

\subsection{Bark Use Survey}

According to the interviewed informants, the top ten exploited species were: Sclerocarya birrea (A. Rich.) Hochst. (Anacardiaceae), Kigelia africana (Lam.) Benth. (Bignoneaceae), Garcinia livingstonei T. Anderson (Clusiaceae), Terminalia sericea Burch. ex DC. (Combretaceae), Albizia adianthifolia (Schumach.) W. Wight, A. versicolor Welw. Ex Oliv., Dialium schlechteri Harms (Fabaceae), Trichilia emetica Vahl (Meliaceae), Manilkara discolor (Sond.) J. H. Hemsl. (Sapotaceae), and Strychnos sp. (Strychnaceae). The results of the ethnobotanical survey are summarized in Table 1. With the exception of Strychnos sp., the barks of all cited species were mainly used for medicinal purposes, spanning 13 different applications (Table 2). The number of species used for medicinal purposes and their potential applications reflect the rich ethnomedicinal knowledge in the 
Madjadjane community. Similar potentialities were also referred in other surveys carried out in Mozambique [6] [13] [14] as well as in the region [e.g. [15]-[17]].

Several species were found to be used against major ailments such diarrhea (A. adianthifolia, G. livingstonei, K. africana, S. birrea and T. emetica), anal wounds (A. adianthifolia, A. versicolor, G. livingstonei, K. africana, T. emetica and T. sericea), and stomach ache (A. adianthifolia, G. livingstonei, K. africana, S. birrea, T. emetica and $T$. sericea). In Mozambique digestive system disorders have long been associated with a complex array of illnesses. Amongst them, dysentery and cholera usually have a high mortality rate if not treated promptly [6]. Together with the observations of [6] [13] [14] our results confirm the key role of traditional medicine in controlling digestive system-associated diseases.

Three species (K. africana, M. discolor, S. birrea) were used to treat tooth ache and two served as cough suppressants (A. versicolor and S. birrea), disinfectants (K. Africana and T. emetica) and wound treatments (A. adianthifolia and $D$. schlechteri). Only one species was cited for the remaining applications: burn care (D. schlechteri), female infertility and flu (S. birrea), malaria (G. livingstonei), menstrual pain (T. emetica) and rheumatism (D. schlechteri). Considering the three major national health concerns, namely diarrhea/dysentery, malaria and HIV-AIDS a considerable number of bark potentialities seem to be available only for the first group (five species). This does not necessarily suggest that there are fewer medicinal plant options for malaria and HIV-AIDS. First, alternative species or sources other than bark may be used for malaria and HIV-AIDS control in the surveyed community. Second, it may reflect the incipient nature of ethnobotanical and ethnopharmacological research in the country and in the region. In fact, among the ten surveyed species, besides G. livingstonei (this work and [18]), K. africana, S. birrea and T. emetica were previously referred as potential sources of antimalarial compounds [11] [19] [20].

The bark of seven out of the top ten cited species had more than one medical application (Table 2). S. birrea was the most versatile (six applications), followed by K. africana and T. emetica (five), A. adianthifolia and G. livingstonei (four), D. schlechteri (three), and A. versicolor and T. sericea (two). Compared to other studies in Mozambique [6] [13] [14] [21] [22] and in the region [23] [24], it can be seen that $S$. birrea is one of the most

Table 1. List of 10 most used surveyed species and local uses of bark.

\begin{tabular}{|c|c|c|c|}
\hline Scientific name $^{*}$ & Local/Common names & Medicinal uses of bark & Other uses \\
\hline \multicolumn{4}{|l|}{ Anacardiaceae } \\
\hline $\begin{array}{c}\text { Sclerocarya birrea (A. Rich.) } \\
\text { Hochst. }\end{array}$ & Canho/Marula & $\begin{array}{l}\text { Cough; Diarrhea; Female infertility; Flue; } \\
\text { Stomach ache; Tooth ache }\end{array}$ & Detergent; Firewood \\
\hline \multicolumn{4}{|l|}{ Bigoneaceae } \\
\hline Kigelia africana (Lam.) Benth. & Pfungura/Sausage Tree & $\begin{array}{l}\text { Anal wounds*; Diarrhea; Disinfectant; } \\
\text { Stomach ache; Tooth ache }\end{array}$ & None \\
\hline \multicolumn{4}{|l|}{ Clusiaceae } \\
\hline Garcinia livingstonei T. Anderson & Phimbi/Africanmangosteen & $\begin{array}{c}\text { Anal wounds; }{ }^{*} \text { Diarrhea; Malaria; Stomach } \\
\text { ache }\end{array}$ & None \\
\hline \multicolumn{4}{|l|}{ Combretaceae } \\
\hline Terminalia sericea Burch. ex DC. & Nkonola/Silvercluster-leaf & Anal wounds*; Stomach ache & Detergent \\
\hline \multicolumn{4}{|l|}{ Fabaceae } \\
\hline $\begin{array}{l}\text { Albizia adianthifolia (Schumach.) W. } \\
\text { Wight }\end{array}$ & Gowana/Flat-crownalbizia & $\begin{array}{l}\text { Anal wounds*; Diarrhea; Stomach ache; } \\
\text { Wounds }\end{array}$ & Detergent \\
\hline Albizia versicolor Welw. ex Oliv. & Mphisso/Poison-podalbizia & Anal wounds*; Cough & Detergent \\
\hline Dialium schlechteri Harms & Ndziva/Sherbettree & Burnings; Rheumatism; Wounds & Beehives; Strings \\
\hline \multicolumn{4}{|l|}{ Meliaceae } \\
\hline Trichilia emetica Vahl & Kalhu/Natal-mahogany & $\begin{array}{l}\text { Anal wounds*; Diarrhea;Disinfectant; } \\
\text { Menstrual ache; Stomach ache }\end{array}$ & Pottery \\
\hline \multicolumn{4}{|l|}{ Sapotaceae } \\
\hline $\begin{array}{l}\text { Manilkara discolor (Sond.) } \\
\text { J. H. Hemsl. }\end{array}$ & Nheve/Forest milkberry & Tooth ache & None \\
\hline \multicolumn{4}{|l|}{ Strychnaceae } \\
\hline Strychnos sp. & $-/-$ & - & $\begin{array}{l}\text { House construction; } \\
\text { Strings }\end{array}$ \\
\hline
\end{tabular}

\footnotetext{
*Associated to diarrhea/dysentery, parasites, hemorrhoids or obstipation.
} 
Table 2. Medical applications of the bark from the top-10 cited species.

\begin{tabular}{cc}
\hline Category & Species \\
\hline Anal wounds & Albizia adianthifolia, A. versicolor, Garcinia livingstonei, Kigelia africana, Terminalia sericea, Trichilia emetica \\
Burnings & Dialium schlechteri \\
Cough & A. versicolor, Sclerocarya birrea \\
Diarrhea & A. adianthifolia, G. livingstonei, K. africana, S. birrea, T. emetica \\
Disinfectant & K. africana, T. emetica \\
Female infertility & S. birrea \\
Flue & S. birrea \\
Malaria & G. livingstonei \\
Menstrual ache & T. emetica \\
Rheumatism & D. schlechteri \\
Stomach ache & A. adianthifolia, G. livingstonei, K. africana, S. birrea, T. sericea, T. emetica \\
Tooth ache & K. africana, Manilkara discolor, S. birrea \\
Wounds & A. adianthifolia, D. schlechteri \\
\hline
\end{tabular}

culturally important medicinal tree. It is a "multi-purpose, whole plant use": roots, stems, bark, leaves, branch and fruits are employed to treat various ailments (e.g. cough, intestine and stomach disorders, anemia, tooth ache, and ear infections) [3] [6] [13] [14] [21]-[24]. The species also has several non-medical cultural values, including myths and beliefs, ornamentation, food, handicrafts and wood [13] [21] [22]. Recently, the anticancer [25], anti-microbial (respiratory infections) [26], anti-diabetic and anti-oxidant ability of S. birrea [27] as well as a set of compounds and molecules related to these diseases [28] have been reported. In addition, the fruits of this species are highly nutritive, with unusually high contents of micronutrients, protein (ca. 30\%) and fat (ca. 60\%) [21] [22]. To a lesser extent, excepting M. discolor, the remaining species also represent potential sources of biocompounds (e.g. [11] [15]-[17] [20] [23] [29] [30]).

The bark of seven species was also used for non-medical purposes (Table 1), especially as a detergent ( $A$. adianthifolia, A. versicolor, S. birrea and T. sericea). Other applications include strings (D. schlechteri and Strychnos sp.), beehives (D. schlechteri), pottery (T. emetica), and house construction (Strychnos sp.). This reinforces the socio-economic importance of the reported species, placing them in a privileged position for conservation aspects and income-generating purposes.

\subsection{Damage Level}

The mean density of the top ten species varied from ca. 14 (T. sericea) to 0.70 individuals/ha ( $K$. africana) (Figure 2). The most affected species was K. africana (ca. 80\%) followed by A. adianthifolia (ca. $70 \%$ ), $M$. discolor (ca. 50\%), T. emetica, S. birrea, T. sericea and G. livingstonei (ca. 30\%), and D. schlechteri, Strychnos sp. and A. versicolor (ca. 20\%) (Figure 3). In general the level of damage was related to the species density. Low density species (below four individuals/ha) like M. discolor, T. emetica, G. livingstonei and K. africana exhibited medium (32\% and 50\%) or high (ca. $80 \%$ ) damage, respectively, whereas medium to high density species (T. sericea, A. versicolor, S. birrea, D. schlechteri and Strychnos sp. presented lower damage (below 30\%). A. adianthifolia was one of the most abundant species (ca. 9.5 individuals/ha) and it exhibited the highest level of damage (ca. $80 \%$ ). The fact that this species is used for multiple purposes may explain this observation. When considering the exploitation of $S$. birrea, which exhibits a similar density as A. adianthifolia but lower damage, and whose bark has seven different medical applications plus one non-medical use, it is likely that A. adianthifolia is also among the most preferred species and that $S$. birrea bark has a higher regeneration capacity [31]. It is important to point out that none of the ten species mentioned in this work is in the National Plant Red Data (NPRD) List [30]. They are so far protected by umbrella laws-that appear to be superficial and unenforced, and thus fail to effectively address the conservation status of these species. Therefore, debarking could gradually lead to the loss of resources, particular due to the commercial bark extraction. Two points should be highlighted: 


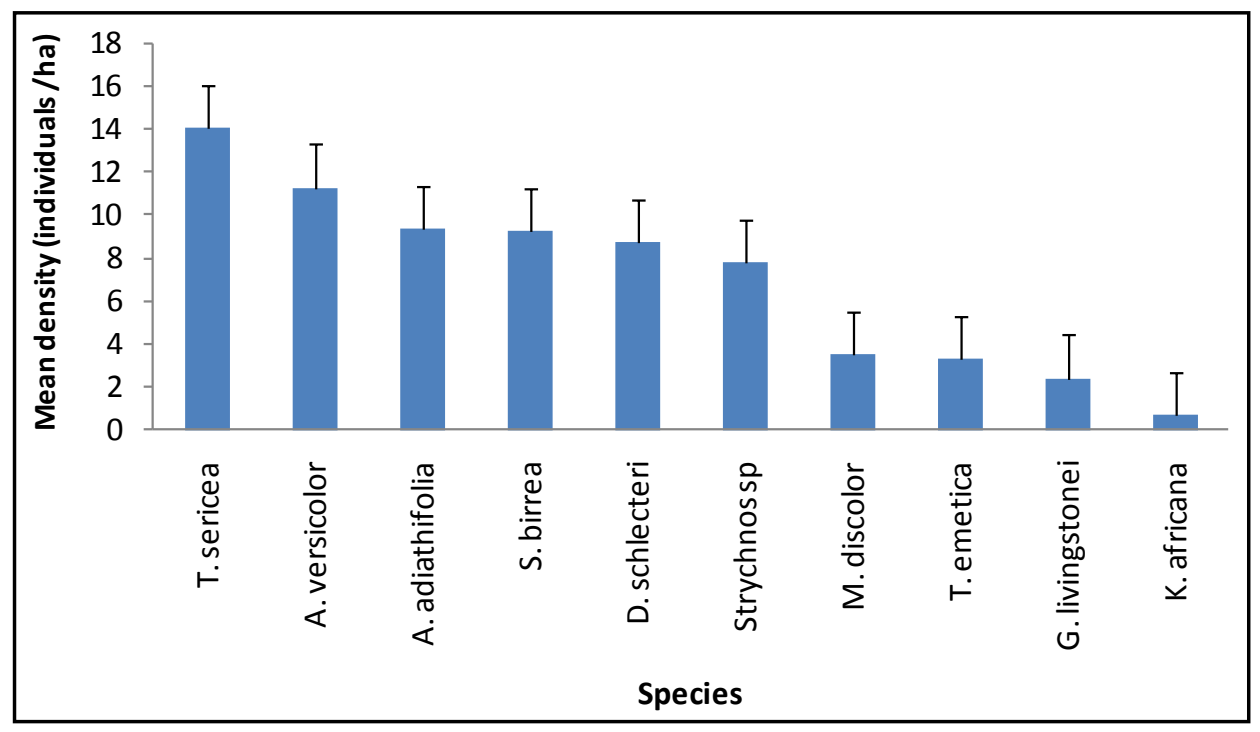

Figure 2. Mean density of the ten selected debarked trees species.

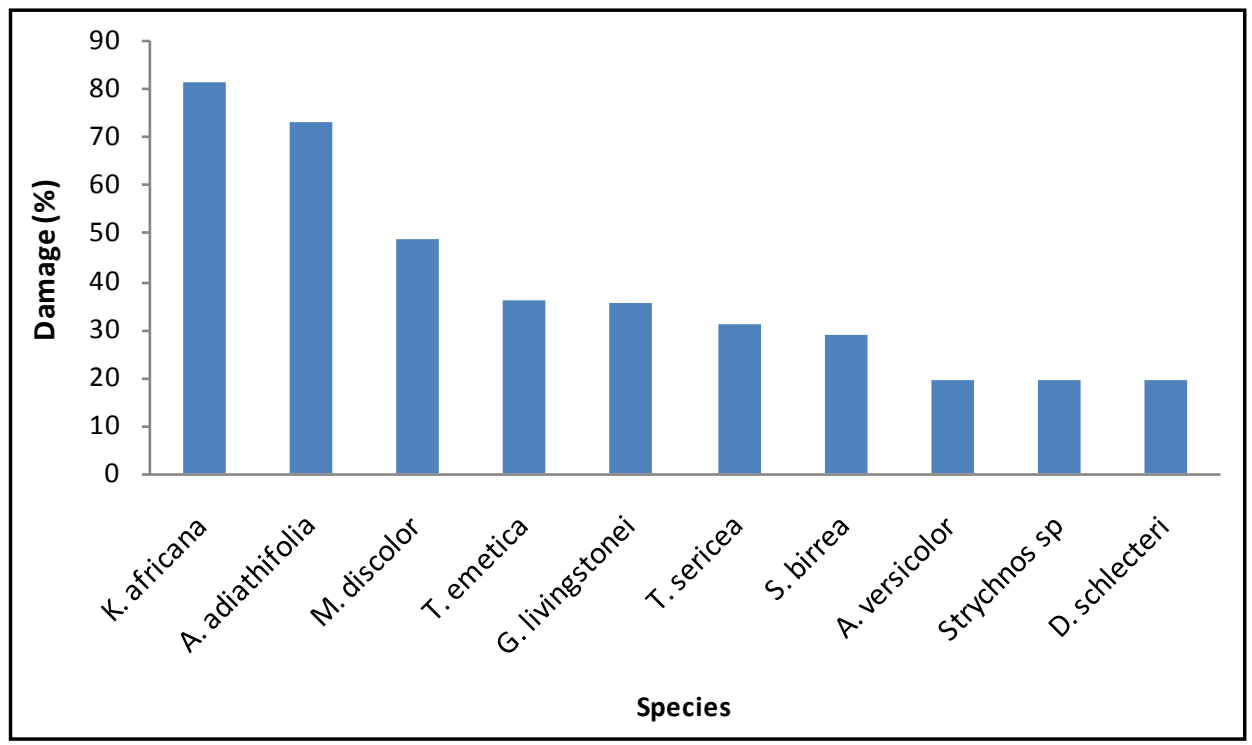

Figure 3. Damage level (\%) caused by debarking on the most exploited trees.

1) the NPRD List is probably outdated; and 2) this survey did not include the quantification of bark per application (dosage), the number of users per species and the frequency of harvesting. Thus, an upgrade and update of the results will be of utmost importance to estimate with more accuracy the current conservation status as well as to predict future impacts and define better conservation strategies.

\section{Concluding Remarks}

The ecological impact of bark stripping is an emerging subject in Africa [31]-[35]. This was the first study in Mozambique to focus on the question of bark exploitation, uses, and impacts. We highlight the major uses of tree bark for medical and other purposes in rural communities, adding to the existing national and regional ethnobotanical databases, and thus minimizing the loss of traditional knowledge. We suggest that ethnobotanical surveys should be expanded in Mozambique, and that the results should be integrated into broad programs aimed at the preservation and valorization of local heritage. This will encourage equitable access and benefit sharing of biodiversity as well as the promotion of bio-based economy. 


\section{Acknowledgements}

The authors would like to express their gratitude to the Madjadjane community, particularly to the informants for their unreserved efforts in transmitting traditional local knowledge. Acknowledgments are also due to botanical collector and translator Aurélio Bechel and António Jossias Langa. We are grateful to Prof. Robert Voeks (California State University, Fullerton, and Department of Biological Sciences, Faculty of Sciences, Eduardo Mondlane University) who kindly edited the English revision, and Eng. Hugo Mabilana (Department of Biological Sciences, Faculty of Sciences, Eduardo Mondlane University) who produced the study site map. This work was supported by a grant from International Union for Conservation of Nature (IUCN) and by the CAMÕES, Instituto da Cooperação e da Língua (Portugal).

\section{References}

[1] Williams, V.L. (2004) Trade and Socio-Economic Value of Forest and Woodland Resources within the Medicinal Plant Market in Johannesburg. In: Lawes, M.J., Eeley, H.A.C., Shackleton, C.M. and Geach, B.G.S., Eds., Indigenous Forests and Woodlands in South Africa. Policy, People and Practice, University of KwaZulu-Natal Press, Pietermaritzburg, 439-472.

[2] Evert, R.F. (2006) Esau’s Plant Anatomy: Meristems, Cells, and Tissues of the Plant Body: Their Structure, Function, and Development. Wiley J. and Sons, Inc.. http://dx.doi.org/10.1002/0470047380

[3] Krog, M., Falcão, M.P. and Olsen, C.S. (2006) Medicinal Plant Markets and Trade in Maputo, Mozambique. Forest \& Landscape Working Papers 16, Danish Center for Forest Landscaping and Planning, KVL.

[4] Jha, S. and Bawa, K.S. (2006) Population, Human Development and Deforestation in Tropical Biodiversity Hotspots. Conservation Biology, 20, 906-912. http://dx.doi.org/10.1111/j.1523-1739.2006.00398.x

[5] Sitoe, A., Salomão, A. and Wertz-Kanounnikoff, S. (2012) The Context of REDD+ in Mozambique: Drivers, Agents and Institutions. CIFOR, Bogor.

[6] Bandeira, S.O., Gaspar, F. and Pagula, F.P. (2001) African Ethnobotany and Healthcare: Emphasis on Mozambique. Pharmaceutical Biolology, 39, 70-73.

[7] Cotton, C.M. (2009) Ethnobotany: Principles and Applications. John Wiley and Sons Ltd., Chichester.

[8] Krebs, C.J. (2009) Ecology: The Experimental Analysis of Distribution and Abundance. Pearson Benjamin Cummings, San Francisco.

[9] Van Wyk, B. and Van Wyk, P. (2001) Field Guide to Trees of Southern Africa. Struik Publishers (PTY) Ltd., Cape Town.

[10] African Plants Database. http://www.ville-ge.ch/musinfo/bd/cjb/africa/

[11] Palgrave, M.C. (2002) Keith Coates Palgrave Trees of Southern Africa. Struik Publishers, Cape Town.

[12] Izidine, S. and Bandeira, S.O. (2002) Mozambique. In: Golding, J.S., Ed., Southern African Plant Red Data Lists, SABONET, Pretoria, 43-53.

[13] Ribeiro, A., Romeiras, M.M., Tavares, J. and Faria, M.T. (2010) EthnobotanicalSurveyin CanhaneVillage, District of Massingir, Mozambique: Medicinal Plants and Traditional Knowledge. Journal of Ethnobiology and Ethnomedicine, 6, 33.

[14] Bruschi, P., Morganti, M., Mancini, M. and Signorini, M.A. (2011) Traditional Healers and Laypeople: A Qualitative and Quantitative Approach to Local Knowledge on Medicinal Plants in Muda (Mozambique). Journal of Ethnopharmacology, 138, 543-563. http://dx.doi.org/10.1016/j.jep.2011.09.055

[15] Naidoo, D., van Vuuren, S.F., van Zyl, R.L. and de Wet, H. (2013) Plants Traditionally Used Individually and in Combination to Treat Sexually Transmitted Infections in Northern Maputaland, South Africa: Antimicrobial Activity and Cytotoxicity. Journal of Ethnopharmacology, 149, 656-667.

[16] Mabona, U., Viljoen, A., Shikanga, E., Marston, A. and Van Vuuren, S. (2013) Antimicrobial Activity of Southern African Medicinal Plants with Dermatological Relevance: From an EthnopharmacologicalScreening Approach, to Combination Studies and the Isolation of a Bioactive Compound. Journal of Ethnopharmacology, 148, 45-55.

[17] De Wet, H., Nciki, S. and van Vuuren, S.F. (2013) Medicinal Plants used for the Treatment of Various Skin Disorders by a Rural Community in Northern Maputaland, South Africa. Journal of Ethnobiology and Ethnomedicine, 9, 51.

[18] Mbwambo, Z.H., Kapingu, M.C, Moshi, M.J., Machumi.F., Apers, S., Cos, P., Ferreira, D., Marais, J.P., Vanden Berghe, D., Maes, L., Vlietinck, A. and Pieters, L. (2006) AntiparasiticActivity of Some Xanthones and Biflavonoids from the Root Bark of Garcinialivingstonei. Journal of Natural Products, 69, 369-372. http://dx.doi.org/10.1021/np050406v

[19] van Wyk, B.E. and Gericke, N. (2002) People’s Plants: A Guide to Useful Plants of Southern Africa. Briza Publica- 
tions, Pretoria.

[20] Zofou, D., Tene, M., Tane, P. and Titanji, V.P. (2012) Antimalarial Drug Interactions of Compounds Isolated from Kigeliaafricana (Bignoniaceae) and Their Synergism with Artemether, Against the Multidrug-Resistant W2mef Plasmodium falciparum Strain. Parasitolgy Research, 110, 539-544. http://dx.doi.org/10.1007/s00436-011-2519-9

[21] Magaia, T., Uamusse, A., Sjöholm, I. and Skog, K. (2013) Proximate Analysis of Five Wild Fruits of Mozambique. The Scientific World Journal, 2013, Article ID: 601435.

[22] Magaia, T., Uamusse, A., Sjöholm, I. and Skog, K. (2013) Dietary Fiber, Organic Acids and Minerals in Selected Wild Edible Fruits of Mozambique. SpringerPlus, 2, 88. http://dx.doi.org/10.1186/2193-1801-2-88

[23] Cheikhyoussef, A. and Embashu, W. (2013) Ethnobotanical Knowledge on Indigenous Fruits in Ohangwena and Oshikoto Regions in Northern Namibia. Journal of Ethnobiology and Ethnomedicine, 9, 34.

[24] De Wet, H., Nkwanyanaa, W.N. and Van Vuuren, S.F. (2010) Medicinal Plants Used for the Treatment of Diarrhoea in Northern Maputaland, KwaZulu-Natal Province, South Africa. Journal of Ethnopharmacology, 130, 284-289.

[25] Tanih, N.F. and Ndip, R.N. (2013) The Acetone Extract of Sclerocarya birrea (Anacardiaceae) Possesses Antiproliferative and Apoptotic Potential against Human Breast Cancer Cell Lines (MCF-7). The Scientific World Journal, 2013, Article ID: 956206.

[26] York, T., van Vuuren, S.F. and de Wet, H. (2012) An Antimicrobial Evaluation of Plants Used for the Treatment of Respiratory Infections in Rural Maputaland, KwaZulu-Natal, South Africa. Journal of Ethnopharmacology, 144, 118127.

[27] Mousinho, N.M., van Tonder, J.J. and Steenkamp, V. (2013) In Vitro Anti-Diabetic Activity of Sclerocarya birrea and Ziziphus mucronata. Natural Product Communications, 8, 1279-1284.

[28] Botes, L., van der Westhuizen, F.H. and Toit Loots, D. (2008) Phytochemical Contents and Antioxidant Capacities of Two Aloe greatheadii var. davyana Extracts. Molecules, 13, 2169-2180. http://dx.doi.org/10.3390/molecules13092169

[29] Agyare, C., Dwobeng, A.S., Agyepong, N., Boakye, Y.D., Mensah, K.B., Ayande, P.G. and Adarkwa-Yiadom, M. (2013) Antimicrobial, Antioxidant, and Wound Healing Properties of Kigelia africana (Lam.) Beneth. and Strophanthus hispidus DC. Advances in Pharmacology Sciences, 2013, Article ID: 692613.

[30] Mulholland, D.A., Mwangi, E.M., Dlova, N.C., Plant, N., Crouch, N.R. and Coombes, P.H. (2013) Non-Toxic Melanin Production Inhibitors from Garcinia livingstonei (Clusiaceae). Journal of Ethnopharmacology, 149, 570-575.

[31] Geldenhuys, C.J. (2004) Bark Harvesting for Traditional Medicine: From Illegal Resource Degradation to Participatory Management. Scandinavian Journal of Forest Research, 19, 103-115. http://dx.doi.org/10.1080/14004080410034182

[32] Stanley, D., Voeks, R. and Short, L. (2012) Is Non-Timber Forest Product Harvest Sustainable in the Less Developed World? A Systematic Review of the Recent Economic and Ecological Literature. Ethnobiology and Conservation, 1, 9.

[33] Geldenhuys, C.J., Syampungani, S., Meke, G.S. and Vermeulen, W.J. (2007) Response of Different Species to Bark Harvesting for Traditional Medicine in Southern Africa. In: Bester, J.J., Seydack, A.H.W., Vorster, T., Van der Merwe, I.J. and Dzivhani, S., Eds., Multiple Use Management of Natural Forests and Woodlands: Policy Refinement and Scientific Progress, Department of Water Affairs and Forestry, Pretoria, 55-62.

[34] Vermeulen, W.J. (2009) The Sustainable Harvesting of Non-Timber Forest Products from Natural Forests in the Southern Cape, South Africa: Development of Harvest Systems and Management Prescriptions. Ph.D. Dissertation, Stellenbosch University, Stellenbosch.

[35] Delvaux, C. (2009) "Strip-Trees”: The Life After. Responses to Bark Harvesting of Medicinal Tree Species from Forêt Classée des Monts Kouffé, Benin. Ph.D. Dissertation, Ghent University, Ghent. 